UDC 543. 42. 062: 546. 77

\title{
COMPOSITION AND EXTRACTION OF TUNGSTEN(VI) COMPLEXES WITH 2- HYDROXY-5-BROMTIPHENOL AND AMINOPHENOLS
}

\author{
A.Z. Zalov, K.A. Kuliev, N.A. Akberov, U.B. Abasgulieva, U.Sh. Bakhsieva \\ Azerbaijani State Pedagogical University \\ Uz. Hadjibekov str., 68, AZ 1000 Baku, e-mail: zalov1966@mail.ru
}

Received 05.01.2019

\begin{abstract}
The interaction of tungsten(VI) with 2-hydroxy-5-bromothiophenol (HBTP) in the presence of aminophenols (APs)was studied as follows:(N,N-diethylaminomethylthio)-4-methoxyphenol $\left(A P_{1}\right), \quad 2-(N, N$-dibuthylaminomethylthio $) \quad$-4-methoxyphenol $\quad\left(A P_{2}\right), \quad 2,6$-bis- $(N, N$ dimethylaminomethyl)-4-methylphenol $\left(A P_{3}\right), 2,6-b i s-(N, N$ - dimethylaminomethyl)-4-chlorophenol $\left(A P_{4}\right), 2-\left(N, N\right.$-dimethylaminomethyl)-4-methylphenol $\left(A P_{5}\right), 2-(N, N$-diethylaminomethyl)-4-bromophenol $\left(A P_{6}\right)$ and 4-chloro-2-(N,N- dimethylaminomethyl)-6-thiophenylmethylphenol $\left(A P_{7}\right)$.The obtained ternary complexes have a composition of 1:2:2 (W:HBTP:AP) or 1:2:1 $\left(\mathrm{AP}_{3}\right.$ and $\left.A P_{4}\right)$. The optimum conditions for their formation and subsequent solvent extraction were found: organic solvent (chloroform), $\mathrm{pH}$ (4.1-5.6), concentration of reagents and extraction time. Degrees of extraction made up 98.1-98.6\%. The complexes have absorption maximum at 470-482 $\mathrm{nm}$ and molar absorptivity coefficients ranged between (2.6-3.9) $\times 10^{4}$. The Beer's law is observed in the range of concentrations of tungsten 0.2-16 $\mu \mathrm{g} / \mathrm{ml}$.
\end{abstract}

Keywords: tungsten (V), solvent extraction, 2-hydroxy-5-bromothiophenol, ternary complex, determination methods

Doi.org/10.32737/2221-8688-2019-1-50-57

\section{INTRODUCTION}

Alloys containing tungsten have valuable properties, including high temperature strength, corrosion resistance, hardness and wear resistance. The tungsten is used in argon-welding electrodes, light bulbs and X-ray tubes.

Methods for determining tungsten based on color reactions with organic reagents are numerous, but only some of them are used in analytical practice [1-3]. 2-hydroxy-5chlorothiophenol [4,5], nitro catechol [6,7], 2,3-dihydroxynaphthalene [7] as well as various ion-binding reagents [8-9] are used for the determination of tungsten. It is known that the hydroxythiophenolate complexes of tungsten are not soluble in chloroform whereas the mixed ligand complexes with hydrophobic amines and aminophenols are well dissolved in various organic solvents. In that respect, a prospective reagent comprising a $-\mathrm{OH}$ and $-\mathrm{SH}$

group in its molecule is 2-hydroxy-5bromothiophenol (HBTP, $\left.\mathrm{H}_{2} \mathrm{R}\right)$. The present work deals with the interaction of tungsten with HBTP in the presence of aminophenols (AP). The following APs were used: 2-(N,Ndiethylaminomethylthio)-4-methoxyphenol $\left(\mathrm{AP}_{1}\right), 2-(\mathrm{N}, \mathrm{N}-$ dibuthylaminomethylthio) -4methoxyphenol $\left(\mathrm{AP}_{2}\right), \quad 2,6-$ bis- $(\mathrm{N}, \mathrm{N}-$ dimethylaminomethyl)-4-methylphenol $\left(\mathrm{AP}_{3}\right)$, 2,6-bis-(N,N- dimethylaminomethyl)-4chlorophenol $\left(\mathrm{AP}_{4}\right), 2-(\mathrm{N}, \mathrm{N}$-dimethylaminomethyl)-4-methylphenol $\left(\mathrm{AP}_{5}\right), \quad 2-(\mathrm{N}, \mathrm{N}-$ diethylaminomethyl)-4-bromophenol $\left(\mathrm{AP}_{6}\right)$ and 4-chloro-2-(N,N-dimethylaminomethyl)6-thiophenylmethylphenol $\left(\mathrm{AP}_{7}\right)$. On the basis of the results obtained, new selective and sensitive procedures for the extraction and photometric determination of tungsten microscopes in steel were developed. 


\section{MATERIALS AND METHODS}

Reagents. The W(VI) stock solution was prepared by dissolving $\mathrm{Na}_{2} \mathrm{WO}_{4} \times 2 \mathrm{H}_{2} \mathrm{O}$ in water. Its exact concentration is established gravimetrically - precipitation of tungsten in the form of acid and weighing of the obtained $\mathrm{WO}_{3}$ [10]. Working solutions at a concentration of $0.1 \mathrm{mg} / \mathrm{mL}$ are obtained by diluting the stock solution. Chloroform solutions of HBTF and AF were used at a concentration of $0.01 \mathrm{~mol} / \mathrm{l}$. HBTP and AP were synthesized according to known methods: [11] and [12], respectively. Their purity was checked by paper chromatography and melting temperature determination. Chloroform is distilled before use.

Apparatus. The absorption of the extracts was read using a photocolorimeter KFK-2 and a spectrophotometer SF-26. For $\mathrm{pH}$ determination a I-120.2 ionometer was used with a glass electrode.

Procedure. In the graduated tubes equipped with ground stoppers, there are a W (VI) solution (0.1 to $0.8 \mathrm{~mL}, 0.1 \mathrm{~mL}$ interval), a solution of HBTP $(2.4 \mathrm{ml})$ and AP solution $(2.2-2.3 \mathrm{~mL})$. The necessary acidity is created by adding solutions of $\mathrm{NaOH}$ or $\mathrm{HCl}$ at a concentration of $0.1 \mathrm{~mol} / \mathrm{l}$. The volume of the organic phase is brought to $5 \mathrm{ml}$ with chloroform and the aqueous phase to $25 \mathrm{~mL}$ (with water). Suffice it to shake for extraction
(15 min) and after complete phase separation, the organic layer is separated and its absorption measured in $0.5 \mathrm{~cm}(490 \mathrm{~nm})$ (KFK-2) wavelength cuvettes.

Procedure for dissolving steels. A weighted amount of steel (depending on the concentration of tungsten in it) is dissolved in $\mathrm{HCl}$ (1:1). A few drops of conc. $\mathrm{HNO}_{3} .60 \mathrm{ml}$ of hot water and $5 \mathrm{ml}$ of $\mathrm{HCl}$ (1:1) were added. It is refluxed for 5 minutes. The resulting yellowish precipitate of tungstic acids was removed by filtration through a blue band filter. The residue was thoroughly washed with $100 \mathrm{ml}$. water and dissolved in a solution of $0.5 \mathrm{~mol} / \mathrm{l} \mathrm{NaOH}$. After cooling, the solution is transferred to a $50 \mathrm{ml}$ volumetric flask. Water is added to the brand.

Experiments related to the reduction of tungsten. It is known that $\mathrm{W}(\mathrm{V})$ forms a dithiol colored compound, and W (VI) is reduced to $\mathrm{W}(\mathrm{V})$ by the reagent itself [3]. To fortify the conclusion, we conducted two series of experiments: 1) interaction between HBTP and W (V) obtained by reduction with $\mathrm{SnCl}_{2}$ and $\mathrm{KI}$ in the hydrochloric acid medium; 2) interaction between HBTP and W (V) in the absence of additional reducers. The products of both reactions were characterized by a maximum at $\lambda=470 \mathrm{~nm}$.

\section{RESULTS AND DISCUSSION}

In a weak acid and neutral medium $(\mathrm{pH}$ 2.0-6.8) the W (V) forms a water-soluble orange compound with HBTP. As the reagent concentration and the $\mathrm{pH}$ rises, the intensity of the coloration increases as well, and with the addition of various $\mathrm{AF}$ and organic solvents under certain conditions, well-extractable triple complexes are obtained.

Choice of solvent. We experimented with various organic solvents - chloroform, carbon tetrachloride, benzene, toluene, xylene, isobutanol, isopentanol, dichloroethane and chlorobenzene. The extractability of the complexes was assessed by the distribution coefficient and the extraction rate. The chloroform, dichloroethane and chlorobenzene solvents were most suitable. All further studies were performed with chloroform.

The content of tungsten in the organic phase was determined photometrically by toluene-3,4-dithiol after reextraction, and the tungsten content in the aqueous phase by difference [5]. 
Table 1. Characteristics on the ternary complex with different AP

\begin{tabular}{lcccccccc}
\hline AP & $\begin{array}{c}\text { Composition } \\
\text { (W: } \\
\text { HBTP:AP) }\end{array}$ & $\mathrm{pH}_{\text {оpt }}$ & $\begin{array}{c}\lambda_{\max }, \\
\mathrm{nm}\end{array}$ & $\begin{array}{c}\Delta \lambda, \\
\mathrm{nm}\end{array}$ & $\varepsilon 10^{-4}$, & $\lg \beta$ & $\lg \mathrm{K}_{\text {ек }}$ & $\begin{array}{c}\text { Adherence } \\
\text { to Beer's } \\
\text { law, } \mu \mathrm{g} / \mathrm{mL}\end{array}$ \\
\hline $\mathrm{AP}_{1}$ & $1: 2: 2$ & $4.2-5.2$ & 470 & 200 & 3.7 & 6.3 & 9.14 & $0.2-13.0$ \\
$\mathrm{AP}_{2}$ & $1: 2: 2$ & $4.7-5.4$ & 480 & 210 & 3.9 & 6.9 & 10.1 & $0.2-16.0$ \\
$\mathrm{AP}_{3}$ & $1: 2: 1$ & $4.3-5.3$ & 482 & 212 & 2.8 & 5.3 & 8.20 & $0.2-13.0$ \\
$\mathrm{AP}_{4}$ & $1: 2: 1$ & $4.5-5.5$ & 475 & 205 & 2.7 & 5.6 & 7.35 & $0.2-13.0$ \\
$\mathrm{AP}_{5}$ & $1: 2: 2$ & $4.5-5.4$ & 473 & 203 & 2.6 & 5.5 & 7.12 & $0.2-15.0$ \\
$\mathrm{AP}_{6}$ & $1: 2: 2$ & $4.1-5.4$ & 479 & 209 & 3.0 & 6.2 & 8.92 & $0.2-14.0$ \\
$\mathrm{AP}_{7}$ & $1: 2: 2$ & $4.2-5.6$ & 477 & 207 & 3.3 & 6.5 & 9.01 & $0.2-16.0$ \\
\hline
\end{tabular}

We have found that the essence of the AF practically does not affect the extent of the tungsten extraction. As for single extraction in chloroform, it is in the range of 98.1-98.6\%.

Effect of pH on the aqueous phase. Tungsten interacts with HBTP at $\mathrm{pH}>1.5$. For the formation and extraction of the various triple complexes, the optimal $\mathrm{pH}$ values are taken in the range of 4.1-5.6 (Table 1). At $\mathrm{pH}$ above, the 7-8 extraction is not practically carried out due to the decrease in the protonation rate of aminophenols.

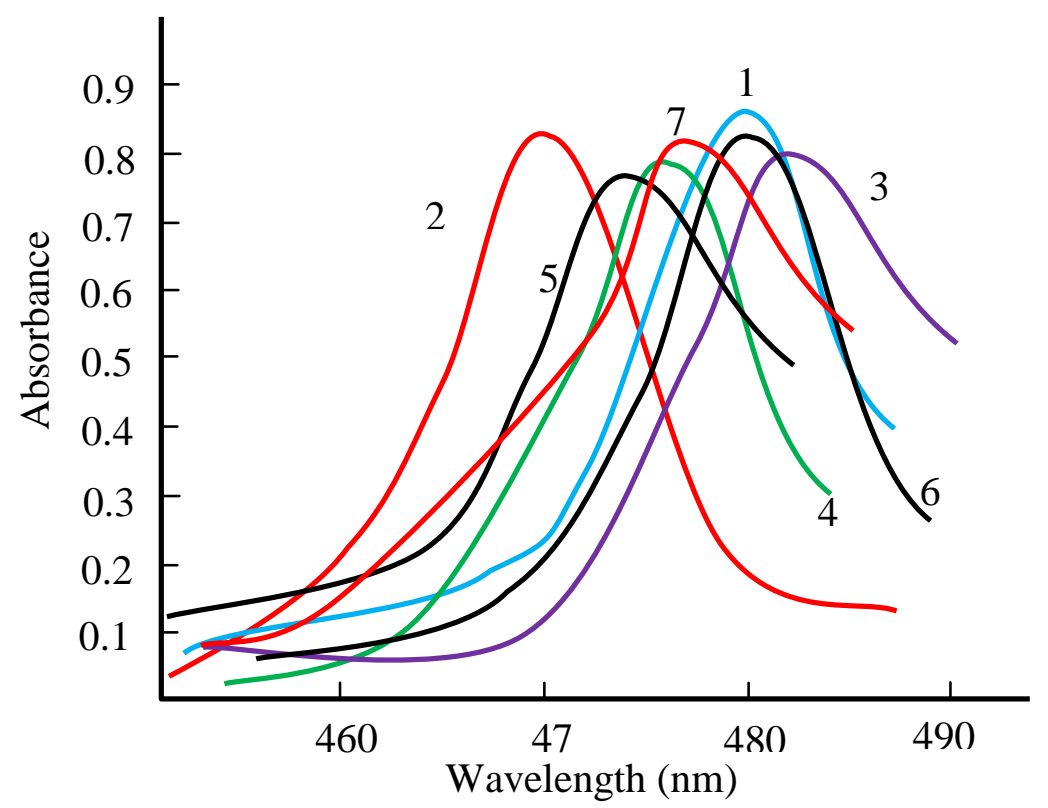

Fig. 1. The absorption spectra of the spectra of W(V)-HBTP-AP under optimal extraction conditions are as follows:

1-W(V)-HBTP-AP $;$ 2-W(V)-HBTP-AP $2 ; 3-\mathrm{W}(\mathrm{V})-\mathrm{HBTP}_{2} \mathrm{AP}_{3} ; 4-\mathrm{W}(\mathrm{V})-\mathrm{HBTP}-\mathrm{AP}_{4} ;$ 5-W(V)HBTP-AP $; 6-\mathrm{W}(\mathrm{V})-\mathrm{HBTP}-\mathrm{AP}_{6} ; 7-\mathrm{W}(\mathrm{V})-\mathrm{HBTP}_{5} \mathrm{AP}_{7}$

$\mathrm{C}_{\mathrm{W}(\mathrm{VI})}=1.09 \times 10^{-5} \mathrm{M} ; \mathrm{C}_{\mathrm{HBTP}}=(9.2-9.6) \times 10^{-4} \mathrm{M} ; \mathrm{C}_{\mathrm{AP}}=(8.8-9.3) \times 10^{-4} \mathrm{M} ; \mathrm{SF}-26 ; \lambda=490 \mathrm{nM} ; \ell=1.0$ $\mathrm{cm}$.

Electronic Spectra. Chloroform extracts of the various complexes have absorption maximum in the range of $470-482 \mathrm{~nm}$. The molar absorbances $\varepsilon$ are in the range of $(2.7$ $3.9) \times 104$. They are higher than those reported in $[4,5,8,9,13,16]$. Table 1 shows that the complexes with AP1 and AP2 involved have the best characteristics. Their spectra are presented in Fig. 1. 
Effect of reagent concentration. For the formation and extraction of triple complexes, the concentration of HBTP in the aqueous phase should be in the range (9.2$9.6) \times 10^{-4} \mathrm{~mol} / \mathrm{l}$, and that of AP - $(8.8-9.3) \times 10^{-4}$ $\mathrm{mol} / \mathrm{l}$. When using chloroform solutions of HBTP, $\mathrm{AP}_{1}$ and $\mathrm{AP}_{2}$ (at a concentration of $0.01 \mathrm{~mol} / \mathrm{l})$, the optimal volumes are $2.4,2.2$ and $2.3 \mathrm{ml}$ respectively. It is not recommended to use larger amounts of aminophenols.

The law of Bern is observed in a wide range of concentrations (Table 1) which allows the use of ternary complexes for the determination of tungsten. The detection limits of the $\mathrm{AP}_{1}$ and $\mathrm{AP}_{2}$ complexes are $0.06 \mathrm{~g} / \mathrm{ml}$ and $0.05 \mathrm{~g} / \mathrm{ml}$ respectively.

Resistance to dyeing and extraction time. Unlike the double complex of W (V)

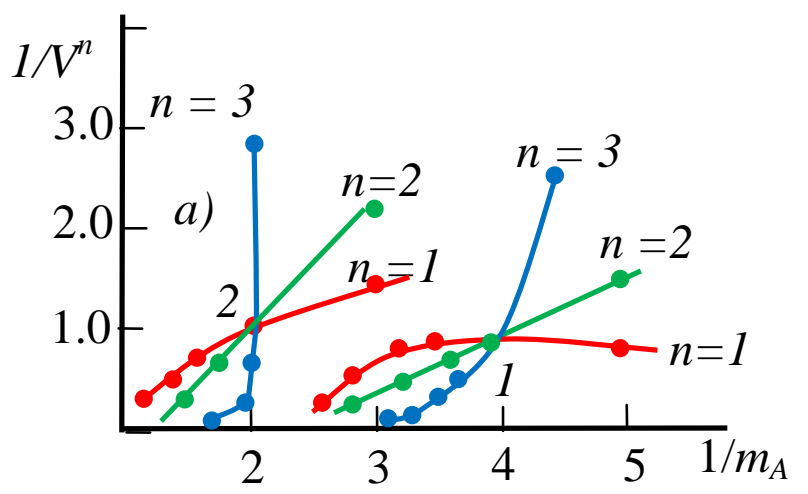

with HBTP, the ternary complexes are resistant to both aqueous and organic solvents. We found that after extraction in chloroform, the staining was stabilized for about a month. To achieve an extraction equilibrium, shake it for approximately for 15 minutes.

Molar relations, elemental analysis and complexation equations. The molar interaction was established by the Asmus method and the equilibrium displacement method [14] (Fig. 2). The results obtained make it possible to conclude that when using $\mathrm{AP}_{1}, \mathrm{AP}_{2}, \mathrm{AP}_{5}, \mathrm{AP}_{6}$ and $\mathrm{AP}_{7}$ the molar ratios are 1:2:2 (W: HBTP: AP). When using the bisaminophenols $\mathrm{AP}_{3}$ and $\mathrm{AP}_{4}$, which may form cations of the $\mathrm{H}_{2} \mathrm{AP}^{2+}$ type, the molar ratios are 1:2:1 (W: HBTP:AP).

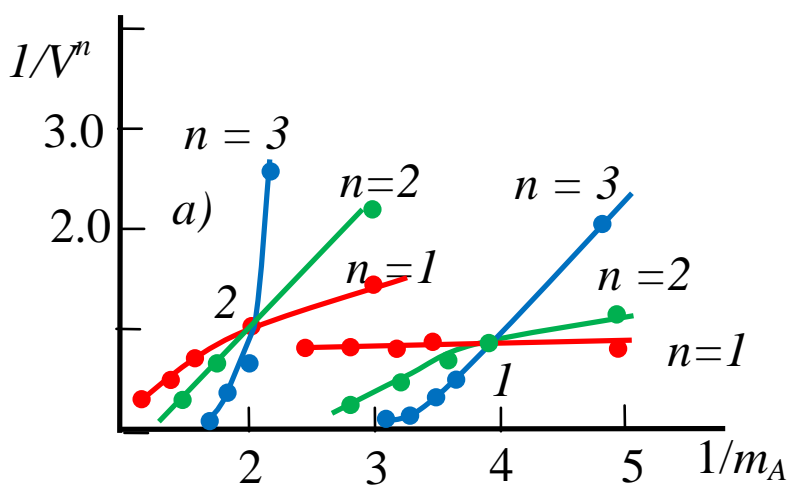

Fig. 2. Determination of the complexes composition by the Asmus method. 1 -W; 2 - AP. a) $\mathrm{W}(\mathrm{V})-\mathrm{R}-\mathrm{AP}_{1}$; for $\mathrm{R}$ and for $\mathrm{AP}_{1} \operatorname{tg} \alpha \approx 2$; b) W(V)-R-AP 3 ; for $\mathrm{R} \operatorname{tg} \alpha \approx 2$; for $\mathrm{AP}_{3} \operatorname{tg} \alpha \approx 1$; $\mathrm{C}_{\mathrm{W}(\mathrm{VI})}=1.09 \times 10^{-5} \mathrm{M} ; \mathrm{SF}-26 ; \lambda=490 \mathrm{~nm}, \ell=1.0 \mathrm{~cm}$.

When adjusted for the molar ratios obtained and the fact that $\mathrm{W}(\mathrm{VI})$ is reduced to $\mathrm{W}(\mathrm{V})$ by HBTP $\left(\mathrm{H}_{2} \mathrm{R}\right)$ (and $\mathrm{W}(\mathrm{V})$ at $\mathrm{pH}$ 3-7 exist mainly in the form of $[\mathrm{WO}(\mathrm{OH})$ and
$\left.[\mathrm{WO}(\mathrm{OH})]^{2+}[1]\right)$, we assume that the complex formation proceeds according to the following equations:

$$
\begin{aligned}
& {[\mathrm{WO}(\mathrm{OH})]^{2+}+2 \mathrm{H}_{2} \mathrm{R} \rightleftarrows\left[\mathrm{WO}(\mathrm{OH}) \mathrm{R}_{2}\right]^{2-}+4 \mathrm{H}^{+}} \\
& {\left[\mathrm{WO}(\mathrm{OH}) \mathrm{R}_{2}\right]^{2-}+2 \mathrm{HAP}_{1}^{+} \rightleftarrows\left(\mathrm{HAP}_{1}^{+}\right)_{2}\left[\mathrm{WO}(\mathrm{OH}) \mathrm{R}_{2}\right]} \\
& {\left[\mathrm{WO}(\mathrm{OH}) \mathrm{R}_{2}\right]^{2-}+\mathrm{H}_{2} \mathrm{AP}_{3}{ }^{2+} \rightleftarrows\left(\mathrm{H}_{2} \mathrm{AP}_{3}{ }^{2+}\right)\left[\mathrm{WO}(\mathrm{OH}) \mathrm{R}_{2}\right]}
\end{aligned}
$$

Equation 2' represents the association of $\left[\mathrm{WO}(\mathrm{OH}) \mathrm{R}_{2}\right]^{2-}$ with the $\mathrm{HAP}+\left(\mathrm{AP}_{1}, \mathrm{AP}_{2}\right.$,

To confirm the relationship between the components in the triple complexes with $\mathrm{AP}_{1}$ and $\mathrm{AP}_{2}$, they were isolated in solid state and assayed by elemental analysis:
$\mathrm{AP}_{5}, \mathrm{AP}_{6}$ and $\left.\mathrm{AP}_{7}\right)$ cations, and $\left(\mathrm{AP}_{3}\right.$ and $\left.\mathrm{AP}_{4}\right)$ equation 2 ".

$\left(\mathrm{HAP}_{1}\right)_{2}\left[\mathrm{WO}(\mathrm{OH}) \mathrm{R}_{2}\right]$ - \{Calculated,\%: 19.19 W, 16.68 Br, 6.67 S, 2.92 N; Found,\%: 19.43 $\mathrm{W}, \quad 16.37 \mathrm{Br}, \quad 6.63 \mathrm{~S}, \quad 2.76 \mathrm{~N}\}$ and $\left(\mathrm{HAP}_{2}\right)_{2}\left[\mathrm{WO}(\mathrm{OH}) \mathrm{R}_{2}\right]-\{$ Calculated,\%: 14.72 
$\mathrm{W}, 12.80 \mathrm{Br}, 5.12 \mathrm{~S}, 2.24 \mathrm{~N}$; Found,\%: $14.62 \mathrm{~W}, 12.74 \mathrm{Br}, 5.09 \mathrm{~S}, 2.11 \mathrm{~N}$ \}.
Equilibrium and extraction constants. On the basis of equation (2'), the following equilibrium constants can be written:

$$
\beta=\frac{\left\{\left(H A P_{1}\right)_{2}\left[W O(O H) R_{2}\right]\right\}_{o}}{\left\{\left[W O(O H) R_{2}\right]^{2-}\right\}_{a q}\left\{\left(H A P_{1}\right)^{2}\right\}_{a q}}
$$

The distribution coefficient (D) is equal to

$$
D=\frac{\left\{\left(H A P_{1}\right)_{2}\left[W O(O H) R_{2}\right]\right\}_{o}}{\left\{\left[W O(O H) R_{2}\right]^{2-}\right\}_{a q}}
$$

therefore

$$
\beta=\frac{D}{\left[H A F_{1}^{+}\right]^{2}}
$$

When logging, we get

$$
\lg \beta=\lg D-2 \lg \left[\mathrm{HAP}_{1}{ }^{+}\right]
$$

and in the case of $\mathrm{AP}_{3}$ and $\mathrm{AP}_{4}$ (equation 2)

$$
\lg \beta=\lg D-\lg \left[\mathrm{H}_{2} \mathrm{AP}_{3}{ }^{2+}\right]
$$

We calculated the extraction constants according to the equations

$$
\begin{aligned}
& \lg K_{e \kappa}=\lg D-2 \lg \left[\mathrm{HBTP}^{2-}\right]-2 \lg \left[\mathrm{HAP}_{1}^{+}\right] \\
& \lg K_{e \kappa}=\lg D-2 \lg \left[\mathrm{HBTP}^{2-}\right]-\lg \left[\mathrm{H}_{2} \mathrm{AP}_{3}{ }^{2+}\right]
\end{aligned}
$$

The results of the calculations are presented in Table 1 .

To determine the degree of aggregation equation set out in [15]. Calculations show that of the complexes in the organic phase, we all complexes are in monomeric form $(\gamma=0.9$ calculated the degree of polymerization by 1.2).

Table 2. Comparative characterization of tungsten determination procedures

\begin{tabular}{|c|c|c|c|c|c|c|}
\hline Reagent(s) & $\mathrm{pH}$ & Solvent & $\begin{array}{c}\lambda, \\
\mathrm{nm}\end{array}$ & $\varepsilon \cdot 10^{-4}$, & $\begin{array}{c}\text { Linear } \\
\text { interval, } \\
\mu \mathrm{g} / \mathrm{ml} \mathrm{W}\end{array}$ & {$[$ Ref.] } \\
\hline Toluene-3,4-dithiol & $1.5-2.0$ & chloroform & 640 & 1.92 & - & {$[2]$} \\
\hline 8-Mercaptoquinoline & $0.5-3.0$ & isobutanol & 412 & 0.367 & $\leq 4$ & {$[1]$} \\
\hline 8-Hydroxyquinoline & 4.4 & chloroform & 363 & 0.64 & - & {$[1]$} \\
\hline 4-nitrocatehol & $1.2-3.6$ & chloroform & 415 & 2.8 & $0.9-8.8$ & {$[13]$} \\
\hline $\begin{array}{c}\text { 3-hydroxy-2- (2'- } \\
\text { thienyl) -4-oxo-4H- } 1- \\
\text { benzopyran }\end{array}$ & $\begin{array}{c}0.2 \mathrm{M} \\
\mathrm{HCl}\end{array}$ & dichloromethane & 415 & 6.45 & $0-2.8$ & {$[16]$} \\
\hline HBTP $+\mathrm{AP}_{1}$ & $2.0-5.8$ & chloroform & 470 & 3.7 & $0.2-13.0$ & This work \\
\hline HBTP $+\mathrm{AP}_{2}$ & $2.2-5.9$ & chloroform & 480 & 3.9 & $0.2-16.0$ & \\
\hline
\end{tabular}


Table 3. Results of tungsten determination in steel $339(\mathrm{~W}-0.183 \%, n=5, P=95 \%$ )

\begin{tabular}{lc|cc}
\hline \multicolumn{2}{c|}{ Method } & $\overline{\mathrm{X}}, \%$ & $\mathrm{RSD}, \%$ \\
\hline \multirow{2}{*}{ Our Methods* } & HBTP $+\mathrm{AP}_{1}$ & $0.180 \pm 0.011$ & 5 \\
& HBTP $+\mathrm{AP}_{2}$ & $0.182 \pm 0.007$ & 3 \\
\hline Toluene-3,4-dithiol [2] & & $0.185 \pm 0.009$ & 4 \\
\hline
\end{tabular}

* - In the presence of $2 \mathrm{~mL}$ thioglycolic acid at a concentration of $0,01 \mathrm{~mol} / \mathrm{L}$

Effect of foreign ions and masking reagents. To assess the applicability of ternary complexes for the determination of tungsten in real objects, the influence of side ions was studied. It should be noted that a large amount of alkaline, alkaline- and rare-earth ions $\mathrm{F}^{-} \mathrm{Cl}^{-}$ , $\mathrm{Br}^{-}, \mathrm{SO}_{3}{ }^{2-}, \mathrm{SO}_{4}{ }^{2-}$ and $\mathrm{C}_{2} \mathrm{O}_{4}{ }^{2-}$ does not affect the definition. The inhibitory effect of Fe (III) was removed by means of thioglycolic acid (0.01 mol/l, $2 \mathrm{ml})$; Ti(IV) - ascorbic acid $\mathrm{Cu}$ (II) by means of thiourea $\mathrm{Mo}(\mathrm{VI})$ with oxalate. When using EDTA, the definition does not interfere with Ti (IV), $\mathrm{V}$ (IV), $\mathrm{Nb}$ (V), Ta (V), Mo (VI) and Fe (III).
Comparative characteristics of the procedures for determining $\mathbf{W}$. Table 2 includes data that compare the analytical characteristics of the procedures developed by us with those of the already known procedures $[1,2,13,16]$.

Table 3 shows the results of the real object analysis - steel 339 (W content $0.183 \%$ ). It can be concluded that the proposed procedures based on the use of HBTP and aminophenols $\mathrm{AP}_{1} \mathrm{AP}_{2}$ are not inferior to those described in the literature. They allow reasonable, selective, accurate, cheap and reliable determination of tungsten in real objects.

\section{REFERENCES}

1. Marchenko Z., Bal'tsezhak M. Metody spektrofotometrii $v$ UF $i$ vidimoy oblastyakh $v$ neorganicheskom analize [Spectrophotometry methods in the UV and visible regions in inorganic analysis]. Moscow: BINOM. Lab knowledge. 2007, 730 p.].

2. Verdizade N.A., Amrakhov T.I., Kuliev K.A., Zalov A.Z. 2-hydroxy-5chlorothiophenol as new analytical reagent for determination of $\mathrm{V}(\mathrm{V})$, Mo and W. Zhurnal Analiticheskoj Khimii Journal of Analytical Chemistry. 1997, vol. 52, no. 10, pp. 1042-1046. (In Russian).

3. Zalov A.Z., Verdizade N.A. Extraction spectrophotometry determination of tungsten with 2-hydroxy-5chlorothiophenol and hydrophobic amines. Zhurnal Analiticheskoj Khimii Journal of Analytical Chemistry. 2013, vol. 68, pp. 212-217. (In Russian).

4. Novruzova N.A., Verdizade N.A., Mamedova R.A., Zalov A.Z. A study of complex formation of tungsten(VI) with 2-hydroxy-5-bromothiophenol and aminophenols. Chemical problems. 2018, no. 1 (16), pp. 105-113.

5. Gavazov K.B. Nitroderivatives of catechol: from synthesis to application. Acta Chim. Slov. 2012, vol. 59, no. 1, pp. 1-17.

6. Dimitrov A., Alexandrov A. Investigation of the extraction equilibrium of ternary ion -association complexes of wolfram(VI) with some polyphenols and tetrazolium salts. Determinationof wolfram. Anal. Lab. 1995, no. 4, pp. 172-179.

7. Verdizadeh N.A., Zalov A.Z., Aliyev S.G. Amanullayeva G.I. Liquid-liquid extraction-chromogenic systems containing tungsten (VI), 2-Hydroxy-5Chlorothiophenol and Dipheny lguanidine. International Journal of Chemical Studies. 2016, vol. 4, pp. 7-13.

8. Masti S.P. Extractive spectrophotometric determination of tungsten (VI) in alloy 
steels using ethopropazine hydrochloride. Analytical Sciences: the International Journal of the Japan Society for Analytical Chemistry. 2002, vol. 18, no. 8, pp. 913-916.

9. Gavazov K.B., Lekova V.D., Dimitrov A.N. Extraction-Spectrophotometric Determination of Molybdenum, Tungsten and Vanadium in Products of Ferrous Metallurgy as Ternary Complexes with Polyphenols and Tetrazolium Salts.13 ${ }^{\text {th }}$ International Metallurgy \& Materials Congress, Congress E-book, Istanbul, 2006, pp. 1305-1312.

10. Korostelev P.P. [Preparation of solutions for chemical analysis works]. Moscow: Publishing house of Academy of Sciences of the USSR. 1964, p. 401.

11. Kuliev A.M., Aliev S.R. Movsumzade M. Synthesis of aminomethyl derivatives of 2-hydroxy-5-tert-alkylthiophenols and their cleavage by thiols. Zhurnal organicheskoj khimii - Russian Journal of Organic Chemistry. 1976, vol. 12, no. 2, pp. 426-430.

12. Mamedov F. N., Mamedov F. A. Method of obtaining multi-functional additives, A.S. 182168 (USSR), B.I., no.

\section{1, 1966].}

13. Lekova V., Gavazov K., Dimitrov A. Application of a ternary complex of tungsten(VI) with 4-nitrocatechol and thiazolyl blue for extractionspectrophotometric determination of tungsten. Chemical Papers. 2006, vol. 60, no. 4, pp. 283-287.

14. Bulatov M.I., Kalinkin I.P. Prakticheskoe rukovodstvo po fotokolorimetricheskim I spektrofotometricheskim metodam analiza [Practical Guide on Photocolorimetric and Spectrophotometric Methods of Analysis]. Moscow: Khimiya Publ. 1986, p. 432.

15. Akhmedli M.K., Klygin A.Ye., Ivanova L. I., Bashirov E.A. On the chemistry of interaction of gallium ions with a number of sulphophtaleins. Russian Journal of Inorqanic Chemistry. 1974, vol. 19, no. 8, pp. 2007-2012.

16. Agnihotri K., Mehta J.R. Extractivespectrophotometric determination of tungsten(VI) using 3-hydroxy-2-(2'thienyl)-4-oxo-4H-1-benzopyran. Annali di Chmica Rome. 2004, vol. 94, pp. 341345 .

\title{
VOLFRAMIN (VI) 2-HIDROKSİ-5-BROMTIOFENOL VO AMINOFENOLLARLA KOMPLEKSLORININ TORKIBİ VO EKSTRAKSIYYASI
}

\author{
Ә.Z. Zalov, K.Ә. Quliyev, N.Ә. Әkborov, Ü.B. Abaşquliyeva, Ü.Ş. Baxşıyeva \\ Azarbaycan Dövlat Pedaqoji Universiteti \\ Uz. Hacıbəyov 68, AZ 1000 Bakl; e-mail: zalov1966@mail.ru
}

Volframin (VI) 2-hidroksi-5-bromtiofenol(HBTF) va aminofenollarla - 2-(N, N-dietilaminometiltio) -4metoksifenol $\left(A F_{1}\right)$, 2- (N,N-dibutilaminometil)-4-metoksifenol $\left(A F_{2}\right), 2,6$-bis- $(N, N$-dimetilaminometil)-4metilfenol $\left(A F_{3}\right), \quad 2,6$-bis- $(N, N$-dimetilaminometil $)-4$-xlorofenol $\left(A F_{4}\right), 2-(N, N$-dimetilaminometil $)$-4metilfenol $\left(A F_{5}\right), 2-\left(N, N\right.$-dietilaminometil) -4-bromofenol $\left(A F_{6}\right)$ va 4-xlor -2- (N,N-dimetilaminometil) -6tiofenilmetilfenol $\left(A F_{7}\right)$ qarşıllqql tasiri tadqiq edilmişdir. Alınan müxtalifliqandlı komplekslari 1:2:2 (W:HBTF:AF) va ya 1:2:1 $\left(A F_{3}\right.$ va $\left.A F_{4}\right)$ tərkibina malikdir. Onların amalagalməsi va ekstraksiyası üçün optimal şarait - üzvi halledici - xloroform, $p H_{o p}$ (4.1-5.6), reagentlarin qatılĭg va ekstraksiya müddati müayyən edilmişdir. Ekstraksiya daracasi 98.1-98.6\% intervalında dayişir. Komplekslar 470-482 nm-da maksimum işıqudmaya malikdir. Molyar udma amsalı (2.6-3.9) $\times 10^{4}$ toşkil edir. Ber qanununa tabe olma 0.2-16 $\mu \mathrm{g} / \mathrm{ml} \mathrm{W}$ qatıllğında müşahidə olunur.

Açar sözlor: volfram (V), halledici ila ekstraksiya, 2-hidroksi-5-bromotiofenol, üçlü kompleks, tayin metodikast 


\section{СОСТАВ И ЭКСТРАКЦИЯ КОМПЛЕКСОВ ВОЛЬФРАМА (VI) C 2-ГИДРОКСИ-5-БРОМТИФЕНОЛОМ И АМИНОФЕНОЛАМИ}

\section{А.З. Залов, К.А. Кулиев, Н.А. Акперов, Ул.Б. Абаскулиева, Ул. Ш. Бахииева}

Азербайджанский государственный педагогический университет AZ 1000 Баку, ул. У. Гаджибекова, 68; e-mail: zalov1966@mail.ru

Изучено взаимодействие вольфрама (VI) с 2-гидрокси-5-бромтиофенолом (ГБТФ) в присутствии аминофенолов (АФ): 2- (N, N-диэтиламинометилтио) -4-метоксифенола $\left(A \Phi_{1}\right), \quad$ 2-(N,N-дибутиламинометил)-4-метоксифенола $\quad\left(A \Phi_{2}\right), \quad 2,6-б и с-(N, N$ диметиламинометил) 4-метилфенола (АФ, $)$, 2,6-бис- (N, N-диметиламинометил) -4хлорфенола (AФ4), 2-(N,N-диметиламинометил)-4-метилфенола $\left(A \Phi_{5}\right), \quad 2-(N, N-$ диэтиламинометил)-4-бромфенола (АФ $)$ и 4-хлор-2-(N,N-диметиламинометил)-6тиофенилметилфенола $\left(A \Phi_{7}\right)$. Полученные тройные комплексы имеют состав 1:2:2 (W:ГБТФ:АФ) или 1:2:1 (АФ, и АФ $)$. Найдень оптимальные условия их образования и

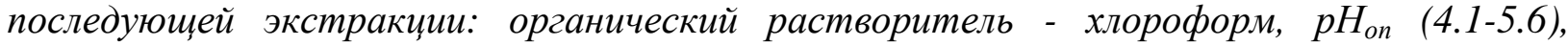
кониентрация реагентов и время экстракиии. Степень экстракиии составляет 98.198.6\%. Комплексы имеют максимумы поглощения при 470-482 нм. Молярные коэффищиенты поглощения составляют (2.6-3.9) $\times 10^{4}$. Закон Бера наблюдается в диапазонах концентрачии вольфрама 0.2 0.2-16.0 мкг/мл.

Ключевые слова: вольфрам (VI), экстракиия растворителем, 2-гидрокси-5бромтиофенол, тройной комплекс, методика определения 